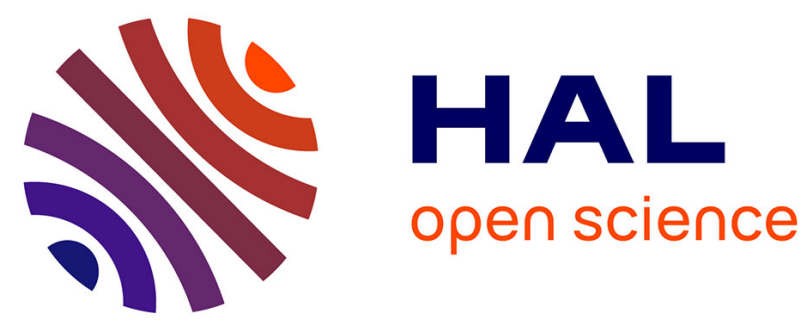

\title{
Enterprise Modeling at the Work System Level: Evidence from Four Cases at DHL Express Europe
}

\author{
Thomas Köhler, Steven Alter, Brian H. Cameron
}

\section{To cite this version:}

Thomas Köhler, Steven Alter, Brian H. Cameron. Enterprise Modeling at the Work System Level: Evidence from Four Cases at DHL Express Europe. 11th IFIP Working Conference on The Practice of Enterprise Modeling (PoEM), Oct 2018, Vienna, Austria. pp.303-318, 10.1007/978-3-030-023027_19. hal-02156464

\author{
HAL Id: hal-02156464 \\ https://hal.inria.fr/hal-02156464
}

Submitted on 14 Jun 2019

HAL is a multi-disciplinary open access archive for the deposit and dissemination of scientific research documents, whether they are published or not. The documents may come from teaching and research institutions in France or abroad, or from public or private research centers.
L'archive ouverte pluridisciplinaire HAL, est destinée au dépôt et à la diffusion de documents scientifiques de niveau recherche, publiés ou non, émanant des établissements d'enseignement et de recherche français ou étrangers, des laboratoires publics ou privés. 


\title{
Enterprise Modeling at the Work System Level: Evidence from Four Cases at DHL Express Europe
}

\author{
Thomas Köhler ${ }^{[1]}$, Steven Alter ${ }^{[2]}$ and Brian H. Cameron ${ }^{[3]}$ \\ ${ }^{1}$ DHL Global Management GmbH, Fritz-Erler-Str. 5, 53113 Bonn, Germany \\ ${ }^{2}$ University of San Francisco, 2130 Fulton Street, San Francisco, CA 94117, United States of \\ America \\ ${ }^{3}$ The Pennsylvania State University, University Park, PA 16802, United States of America
}

\begin{abstract}
Enterprise Architecture is the process of translating business vision into strategy. Hence, Enterprise Modeling is the process of translating an organization's strategic intent into mandated socio-technological innovation projects required to reach an agreed future state of the firm's operation.

This paper uses four longitudinal case studies at DHL Express Europe to introduce a significant paradigm shift to modeling of the enterprise at the work system level as an abstract representation of the desired future state of the enterprise. This representation specifies in full the business capabilities serving current and future customer needs and the work system configuration enhancements needed to satisfy the customer needs. The associated project has four $\mathrm{p}$ steps: 1) Assessment of Status Quo, 2) Agreeing on the desired End-State, 3) Evolution of legacy work-systems, 4) Removal of Obsolete components. This process model explicitly includes the necessity to search for, address and remove all strategic, financial, operational and technical legacy issues identified during the baseline of the status quo. Enterprise Architects should be embedded in each implementation project for Project Assurance purposes in order to monitor the delivery of the agreed end-state.
\end{abstract}

Keywords: Enterprise Modeling, Work System, Work System Framework

\section{$1 \quad$ Need for New Approaches to Enterprise Modeling}

EM methods and tools are like lenses in that they focus on and clarify some topics and issues while downplaying or ignoring others. A general challenge for any lens for EM is apparent from the range of topics and issues often associated with enterprise models and enterprise modelling: rigour AND agility AND business architecture AND IT architecture AND information AND systematic and integrated change AND sense making AND communication between stakeholders AND model deployment and activation AND standardization AND documentation.

Adding a further challenge, a recent article in BISE by widely recognized leaders in the enterprise modeling (EM) community (Sandkuhl et al., 2018) proposes a vision for extending the reach of EM, saying that "EM addresses the systematic analysis and modeling of processes, organization and product structures, IT-systems and any other 
perspective relevant for the modeling purpose (Vernadat 1996)." ... "EM is driven primarily by architects and is valued primarily by IT people so that its effects are often limited to these groups. EM thus appears to be an elitist discipline." A straightforward remedy would be lightweight EM approaches that do not focus on traditional EM qualities like completeness and coherence but on usefulness and impact. Such approaches would need to support not only architects and corporate IT, but also organizational stakeholders that might benefit from improved models supporting their local analysis, design and decision problems.” (p. 71)

An existing lightweight approach. Many aspects of Sandkuhl et al. (2018) call for something like an existing lightweight approach whose initial version was described over two decades ago in a paper called "How should business professionals analyze information systems for themselves?" (Alter, 1995). Applications of that approach were reported in a paper (Truex et al., 2010) called "Systems Analysis for Everyone Else: Empowering Business Professionals through a Systems Analysis Method that Fits Their Needs." That paper describes how 75 working business professionals with extensive business experience used a systems analysis template in MBA assignments that called for analyzing IT-reliant work systems in their organizations and recommending improvements. This paper explains the successful practice of EM based work-system theory and method (WST, WSM respectively). The paper further provides a stepwise approach as proposed by by Sandkuhl et al. (2018). Similar abitions prevailed during the history of WST and WSM. These ambitions intended on providing an organized approach that helps business professionals analyse and understand work systems across enterprises.

The rational of linking WST/WSM and enterprise modeling. Although Bock et al. (2014) included WST along with Archimate, DEMO, and MEMO in its comparison of four enterprise modeling approaches, to date WST/WSM generally has not been viewed as part of the EM discourse because WST/WSM focuses explicitly on analyzing and designing work systems, a conceptual lens that is not widely recognized in the EM community. It could be used for EM, however, because any given enterprise can be viewed as consisting of multiple work systems that can be analyzed and designed using WST/WSM. Models created to date by using WST/WSM have been more informal than models produced by using more formalized EM approaches such as BPMN, Archimate, MEMO, and DEMO. In contrast with the fundamentals of formal modeling languages in Karagiannis and Kühn (2002) and Bork and Fill (2014), (e.g. modeling language, modeling procedure, and mechanisms and algorithms), WST/WSM defines many terms carefully but currently does not have a formal language with defined syntax and notation.

Goal and organization. This practice-oriented paper uses four examples from DHL to illustrate how WST/WSM has been used as an enterprise modelling approach. Illustrating its use in practice demonstrates that an approach that has been used in academic settings by many hundreds of MBA and Executive MBA students producing management briefings about improving work systems also can be incorporated 
into enterprise level projects. The next section summarizes a work system approach to enterprise modelling. Four cases from DHL Express Europe illustrate how ideas from WST/WSM proved effective in enterprise modelling efforts that played important roles in major projects. A final section on conclusions and implications for practice shows how

\section{A Work System Approach to Enterprise Modeling}

The core of WST/WSM is the assumption that the topic at hand is a work system and that work systems can be understood, analysed, and designed using WST. The three comonents of WST - the definition of work system, the work system framework, and work system life cycle model were designed to be straightforward enough to avoid seeming overwhelming to business professionals and researchers who need to think about a work system in an organization but do not need level of detail approaching detailed requirements for software development. This section provides summarizes WST and WSM, both of which have been presented many ties. The next section explains how those ideas were applied in four EM case examples at DHL.

Definition of work system. A work system is defined as a system in which human participants and machines perform processes and activities using information, technology, and other resources to produce product/services for internal and external customers. A work system operates within an environment that matters (e.g., national and organizational cultures, policies, history, competitive situation, demographics, technological change, other stakeholders, and so on). Work systems rely on human, informational, and technical infrastructure that is shared with other work systems. Work systems should support enterprise and departmental strategies. The definition of work system was crafted to make it clear that work system is a very general case that includes many special cases such as information systems, supply chains, service systems, projects, and totally automated work systems. An information system is a working system all of whose activities are devoted to capturing, storing, retrieving, transmitting, manipulating, and displaying information.

The work system framework outlines elements of even a rudimentary understanding of a work system's form, function, and environment as the work system exists during a time interval when its structure is basically stable. In other words the work system is retaining its identity even as minor incremental changes may occur, such as inconsequential personnel substitutions or minor technology upgrades. Placing emphasis on business rather than IT concerns, the work system framework covers situations that might not have a well-defined business process and might not be IT-intensive. Processes and activities, participants, information, and technologies are viewed as completely within the work system. Customers and product/services may be partially inside and partially outside because customers often participate in work systems. Figure 1 presents a version of the work system framework that was modified to incorporate DHL terminology. 
Work system method. WSM is a flexible systems analysis and design method that was developed over several decades to help business professionals visualize work systems in their organizations and collaborate more effectively with IT professionals. To date, almost all students who used WSM did so through work system analysis templates that outlined an organized way to proceed from describing aspects of a work system's structure and performance toward producing a preliminary recommendation about how to improve the work system. Applications of WST in teaching have used various versions of WSM that all embody the same "way of working" individually or in collaboration with business stakeholders and IT professionals:

1) identify the smallest work system that has the problem or opportunity;

2) summarize the "as-is" work system using a work system snapshot, a stylized one page summary;

3) evaluate the work system's operation using measures of performance, key incidents, social relations, and other factors;

4) drill down further as necessary;

5) propose changes by producing a work system snapshot of a proposed "to be" work system that will probably perform better;

6) describe likely performance improvements.

The following discussion of enterprise modelling at the work system level at DHL explains how the above ideas were adapted to make them as effective as possible for the enterprise modelling challenges that DHL faced in those cases.

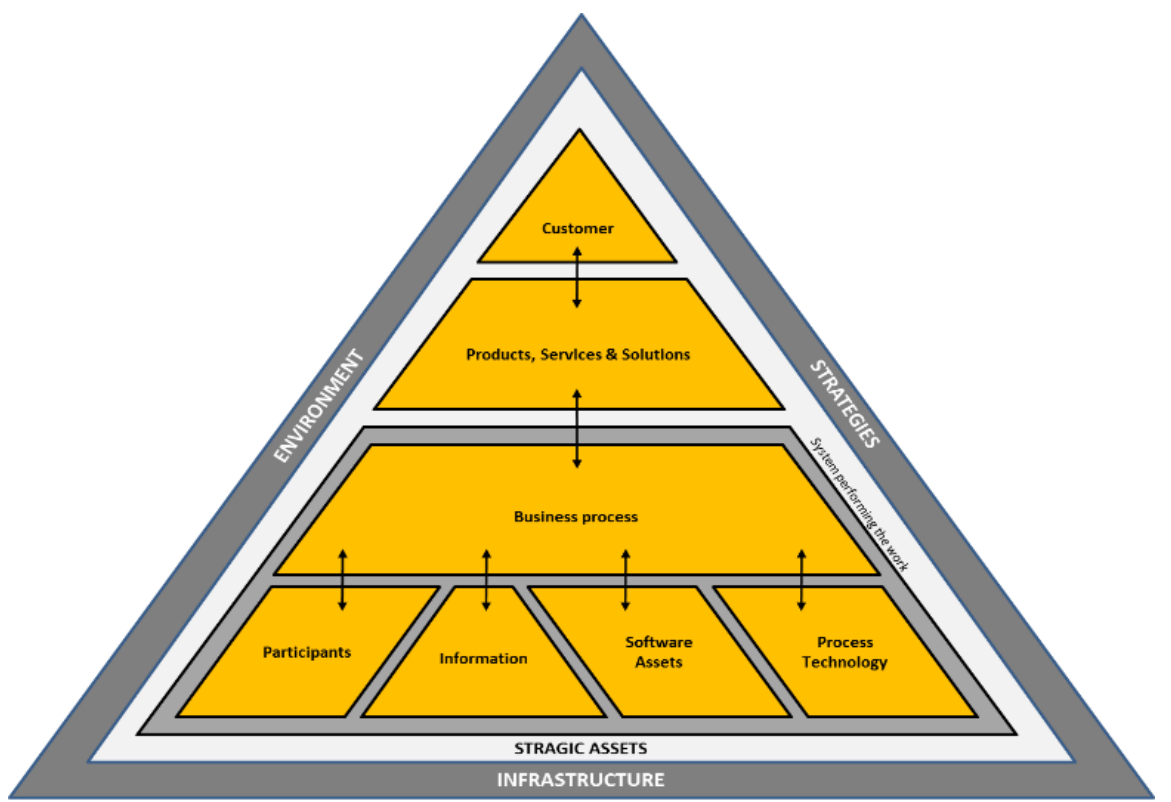

Figure 1: A logistics works system (Köhler and Alter, 2016) 


\section{The Context: DHL Express}

DHL Express ${ }^{1}$. The Deutsche Post DHL Group is the leading global brand in the logistics industry, with about 100,000 employees in over 220 countries and territories worldwide. Its family of divisions provides a portfolio of logistics services including national and international parcel delivery, international express, and road, air, and ocean transport for industrial supply chain management. Deutsche Post DHL's Express division provides specialized solutions for many growth markets and industries. DHL connects people and businesses and serves an important role in global trade. DHL Express serves its customers through more than 500 airports via three main global hubs in Cincinnati, Hong Kong and Leipzig. The airports in its hub and spoke system serve as country gateways linked to over 38,500 service points that serve approximately 1.4 million customers around the world.

DHL Express Europe2 . In 2018 the DHL Express Region Europe 36,000 employees operated roughly 740 daily flights and transported more than 150 million shipments in over 60 countries and territories. Those countries and territories are served from the main hubs in Leipzig (Global Hub), Amsterdam, Bergamo, Brussels, Copenhagen, East Midlands (UK), Frankfurt, London, Madrid, Marseilles, Paris and Vitoria (Spain).

Enterprise Architecture at DHL Express. As DHL grew through mergers and acquisitions, it started to experience redundancy and low-value variation in significant parts of its application system landscape. It became increasingly important to implement an enterprise architecture process that would avoid reinventing existing solutions and would reduce waste due to unnecessary inconsistency across different applications and business units.

DHL Express treats Enterprise Architecture as the process of translating business vision into technology strategy. Supporting this process requires embedding an Enterprise Architect in the cross-functional team managing the translation from an organization's business vision and strategic intent to a road map of the required technological change. This strategic alignment helps exploit technology-supported processes that deliver the outputs needed to create product and service offerings for customers. DHL's enterprise architecture process aims at creating agile work systems that can react quickly to ever-changing market conditions. In other words, enterprise architecture focuses on how the business intends to address threats and opportunities and how to evolve technology as the business environment changes.

Enterprise Modeling at the Logistics Work System Level. Logistics services are processes by nature (Johne and Storey, 1997) and almost always IT-reliant (Davenport, 1993). In DHL Express' approach to enterprise architecture, service providers' product, service and solutions portfolio can be be understood as work systems rather than software or IT systems. Enterprise Architecture thus becomes strategic sociotechnological decision making about how to leverage the system performing the work in support of a predefined set of business capabilities serving customers. The current and future customer needs, the product, service and solution offering have to be

\footnotetext{
${ }^{1}$ Extracts from the DHL Express - GLOBAL Fact Sheet March 2018

${ }^{2}$ Extracts from the DHL Express - EUROPE Fact Sheet March 2018
} 
aligned. This stance treats Enterprise Modeling as the process of understanding current and future customer needs and specifying in full the desired end-state. This desired end-state is then the basis for all associated socio-technological change needed to serve those needs. The associated socio-technological change process has four project-based steps, is an assessment of the status quo, agreeing the desired end-state and the evolution of current legacy work systems in use (Köhler and Alter, 2016). This process model explicitly includes the necessity to search for and address all strategic, financial, operation and technical legacy issues identified during the baseline of the status quo. An important issue in logistics is that sender, payer and recipient benefit from the process with the sender being the contracting party. Hence, implying the term customer in logistics may address up to three parties. Products (e.g. Same Day, Time Definite or Day Definite) and services (e.g. Customers or global trade services) or dedicated solutions (e.g. break bulk cargo or medical express) a works system produces for customers.

Those products, services and solutions need to be understood as the business capabilities delivered by a system performing the work. A "business capability" in logistics is a logistics service provider's ability to execute a defined and repeatable portfolio of standardized business processes to produce the desired outcome (e.g. a Time Definite International service) by deploying specific participants, information, software assets and processing technology in a logistics system performing the work. Thus, customers pay for a business capability which is the output of a system performing the work. This makes the system performing the work the key differentiator.

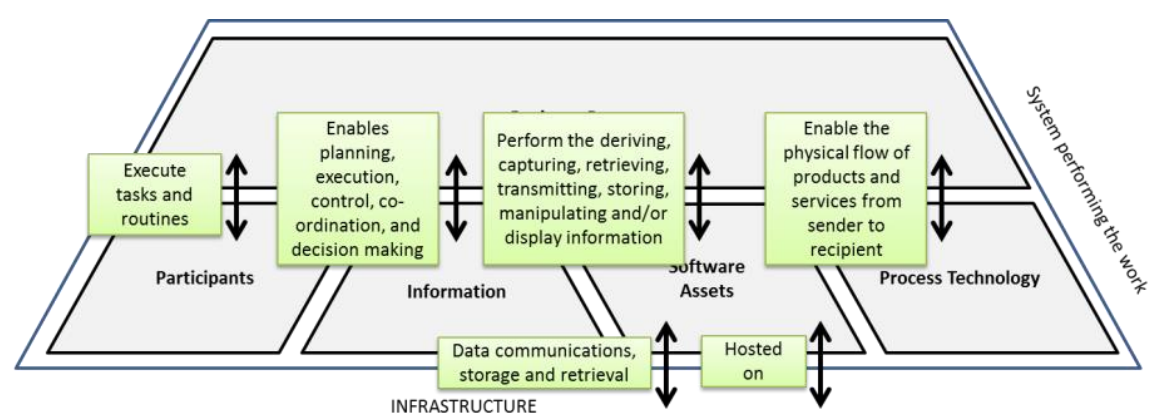

Figure 2: The system performing the work in a logistics work system (Köhler and Alter, 2016)

All business processes in a logistics work system need to be archetypes and associated phases, steps, activities, tasks and routines within the work systems and thus have to be standardized within a logistics network. DHL Express has codified its standards in the Global Standard Operating Procedure. Process technology is used as the label for all tools that increase participant efficiency which is not associated with software assets, like a sorter, plane, lorry or forklift. Participants are people or machines performing at least some of the work in the business process. 
Enterprise Modeling at DHL Express. This paper's main contribution is demonstrating that WST/WSM has been used for enterprise modelling in four significant projects at DHL Express. All four projects were managed as four stand-alone projects.

The first leg of all projects involved taking stock of all capabilities in use and their legacy status. Clustering all capabilities in use by their strategic, financial, operational and technical legacy is the key decision making asset for EAs to achieve business alignment when addressing current and future customer needs. Future customer needs are usually those capabilities DHL's customer had on their roadmap triggering a coevolution of the capability portfolio at DHL.

The second leg involved designing, aligning and agreeing on the desired end-state. Work system proposals addressed this end-state. Each proposal ensured a simultaneous 'clean sweep' of all legacies and innovation of the product, service and solution offering. The key output of this exercise is the framing of socio-technical changes needed in all associated work systems. The aligned and agreed work system evolution proposals will then be forwarded to all suppliers for quotation purposes (i.e. an offer which include costs and timelines). Modeling at the work system level occurred in this second leg. The modelling was based on the portfolio of business capability requirements voiced by the customer. The accountable Senior User acted as the customer's representative. Based on a joint gap analysis (mostly in workshops) Senior Users listed their capability needs. Then the accountable Domain EA modeled the work system to perform the work and codified all necessary changes.

Every capability addressed in the process was scrutinized regarding added value and cash margin generation. Any capability which did not have a defensible business benefit or cash margin was removed from service. In this review, modelling sometimes became controversial when a capability required an architecture change where the cost-case outweighed the benefits. Two noticeable exceptions were those capabilities which are contractually agreed with customers (usually in sales agreements) or legally required. The content of the model included the agreement on the capability definition the system performing the work has to offer (aligned with the global process and capability office and the Senior User) and architecture diagrams (aligned with the global domain EA) to identify all affected vendors. This model was then translated into a project and all documentation by Prince2. Once all work system evolution projects have their Project Briefs, costs and timelines finalized, they were submitted for endorsement in the capability roadmap. This endorsement process at DHL Express included three stage gates. 1) A Project Review Team meeting with all Domain Heads at Vice President level (Finance, HR, Customer Service and so forth). This team conducts quality and feasibility health check, 2) European Project Portfolio Review Board which is the final regional endorsement at C-level (CEO, CFO, COO and so forth), and 3) the Global Project Portfolio Board which is about the final endorsement of resource allocation and all socio-technical changes needed.

At this point, EA modelling was complete from a planning perspective. Nonetheless, certain information provisioning which was contractually agreed with customers could not be handled well existing work systems, especially when those customers used outdated technology. Justified non-compliance or exceptions were addressed 
through dedicated Architecture Concession Agreements that specified why a capability was needed and could be provided by a dedicated stand-alone software asset.

Enterprise Architecture Assurance at DHL Express. From then on, EA was about monitoring the project and gaining awareness of all game changers during implementation in leg three. After project approval, all four projects followed a chain of process innovation landscaping. First, all associated business processes were updated in the Global Standard Operating Procedure. Derived from those updates, the requirements for the evolution of the system performing the work were finalized and defined in manageable and traceable work packages.

Those work packages had three strategic dimensions. The first was the updating of process technology. The second was the augmentation of how participants receive all information when using software assets in a process. These changes fan out into the managed evolution of software in use by corrective, perfective, or adaptive patches of software assets or by new system developments of generic or bespoke software. The third and most important one is participant readying (i.e. training courses) for the tobe process. This includes all alignments with social partners such as work councils or the representative body for disabled employees.

Once all changes were deployed and confirmed by the Senior User, the final cleanup project was started to remove all process technology or software assets that became outdated or obsolete. This included building back all code, decommissioning all hardware, and returning all licenses in use in leg four. The innovation cycle ended with suspending all financial flows to run and host removed legacy items.

A new Architecture Assurance role which currently does not exist in Prince2 (Hedeman and Seegers, 2010) is a direct consequence derived from enterprise modelling in legs three and four. EA modelling is not about an Enterprise Architect producing slide decks and specifications. Rather, it is about supporting Project Board members in four ways:

1. The Executive is supported in all four Business Assurance issues, especially those of performing the work using the agreed to-be business capabilities.

2. The Senior User is supported in all User Assurance matters. All components need to be in alignment, all landscaping activities need to deliver the prealigned socio-technical changes, and those changes need to meet the expected business capabilities serving the current and future customer needs. Therefore, the Enterprise Architect is a permanent member of a project's Change Authority aligning and agreeing on requests for change.

3. The Senior Supplier in his Supplier Assurance role including making sure that all software assets and process technology are delivered as agreed and that the committed resources are in place to do the work.

4. Finally, EA Assurance needs to measure how well the landscaping of the system performing the work delivers the aspired customer promise. This is a key sign-off prerequisite for the removal of obsolete legacy systems. 
This overall stance implies that (using a Prince2 analogy) the accountable Domain Enterprise Architect consults the Program Board and guides the Project Manager in an Architecture Assurance role in all four legs of the innovation cycle.

\section{Four Case Examples from DHL}

Example 1: "Exploratory Case Study"3 . The first case was the first hypothesis testing case of the Clean Sweep approach. Part from this being the exploratory case, it was sufficiently complex as the six implementation quotations addressed various capability enhancements in the current system performing the work.

Table 1: Case 1 summary

\begin{tabular}{|c|c|c|c|c|}
\hline Leg & Timeline & Key Task & Scope & Main Output \\
\hline Project 1 & Q3/2012 & $\begin{array}{l}\text { Review of the } 9 \text { legacy } \\
\text { components in use in } 17 \\
\text { countries in one region }\end{array}$ & 28 capabilities found & $\begin{array}{l}\text { Baseline of the capabilities in use } \\
\text { and assessment of their legacy } \\
\text { status (including the assessment } \\
\text { of opportunities and limiting } \\
\text { factors based on their status) }\end{array}$ \\
\hline Project 2 & Q4/2013 & $\begin{array}{l}\text { Design, align and agree on a } \\
\text { legacy strategy for each } \\
\text { capability and component found }\end{array}$ & $\begin{array}{l}18 \text { capabilities (almost all of them } \\
\text { w orkarounds) w ere made globally } \\
\text { available } \\
10 \text { capabilities classified as } \\
\text { obsolete, outdated or rejected as } \\
\text { no longer adding value }\end{array}$ & $\begin{array}{l}\text { Agreed joint course of action and } \\
\text { decicive points to get the system } \\
\text { performing the w ork in the pre- } \\
\text { defined desired end-state }\end{array}$ \\
\hline Project 3 & Q1/2014 & $\begin{array}{l}\text { Evolution of the system } \\
\text { performing the w ork }\end{array}$ & $\begin{array}{l}6 \text { stand-alone implementation } \\
\text { projects for the } 18 \text { capabilities } \\
\text { agreed to be retained }\end{array}$ & $\begin{array}{l}\text { Landscaping the agreed end-state } \\
\text { and go-live }\end{array}$ \\
\hline Project 4 & Q2/2014 & $\begin{array}{l}\text { Final and conclusive removal of } \\
\text { components having become } \\
\text { obsolete }\end{array}$ & $\begin{array}{l}\text { Code removal, hardw are } \\
\text { decommissioning, Solution Support } \\
\text { contract termination, hosting } \\
\text { contract termination and license } \\
\text { cancellation }\end{array}$ & $\begin{array}{l}\text { Final and conclusive removal of all } \\
\text { strategic, financial, operational } \\
\text { and technical legacy AFTER } \\
\text { operational acceptance of all } \\
\text { landscaping }\end{array}$ \\
\hline
\end{tabular}

DHL replaced

1) two internal Customer Service reports,

2) two reports for country authorities (Shipment information for drug enforcement authorities and shipment information for Customs Investigation and Intelligence),

3) shipments monitoring for various key accounts, real-time reports based on checkpoints raised same day,

4) an interface that allows security staff to search for various shipment details for country authorities (usually requested in relation to a court decision),

5) one local software asset sending invoices to customers via email,

6) a legally required report for a country security bureau,

7) 52 automated interfaces to other data sources or data target systems,

8) a new ad-hoc track and trace queries capability and

9) 51 contractually agreed on customer reports.

3 The in extensor publication of this longitudinal case study can be found under Köhler et al. (2013). 
Example 2: "Hypothesis testing at regional level"4. The second case was the first hypothesis testing case of the Clean Sweep approach. It was the most multinational and most consequential case because it involved 308 capabilities used in 28 countries and took three years to complete. Some model users were hesitant to get involved, but after acknowledging that the exploratory case "SIS" was unsuccessfully attempted seven times and using the Clean Sweep approach delivered.

Table 2: Case 2 summary

\begin{tabular}{|c|c|c|c|c|}
\hline Leg & Timeline & Key Task & Scope & Main Output \\
\hline Project 1 & $\begin{array}{l}\text { Q4/2012 } \\
\text { Q1/2013 }\end{array}$ & $\begin{array}{l}\text { Review of the } 220 \text { legacy } \\
\text { components in use in } 17 \text { countries } \\
\text { in one region }\end{array}$ & 308 capabilities found & $\begin{array}{l}\text { Baseline of the capabilities in use and } \\
\text { assessment of their legacy status } \\
\text { (including the assessment of } \\
\text { opportunities and limiting factors based } \\
\text { on their status) }\end{array}$ \\
\hline Project 2 & $\begin{array}{l}\text { Q1/2013 } \\
\text { Q3/2013 }\end{array}$ & $\begin{array}{l}\text { Design, align and agree on a legacy } \\
\text { strategy for each capability and } \\
\text { component found }\end{array}$ & $\begin{array}{l}44 \text { capabilities (almost all of them } \\
\text { w orkarounds) w ere perceived as } \\
\text { demonstrated best practices and } \\
\text { w ere made globally available } \\
11 \text { capabilities w ere already } \\
\text { available in global operations } \\
\text { systems elsew here } \\
253 \text { capabilities classified as } \\
\text { obsolete, outdated or rejected as no } \\
\text { longer adding value }\end{array}$ & $\begin{array}{l}\text { Agreed joint course of action and } \\
\text { decicive points to get the system } \\
\text { performing the w ork in the pre-defined } \\
\text { desired end-state }\end{array}$ \\
\hline Project 3 & $\begin{array}{l}\mathrm{Q} 4 / 2013 \\
\mathrm{Q} / 2014\end{array}$ & $\begin{array}{l}\text { Evolution of the system performing } \\
\text { the w ork }\end{array}$ & $\begin{array}{l}26 \text { stand-alone implementation } \\
\text { projects for the } 44 \text { capabilities } \\
\text { agreed to be retained }\end{array}$ & $\begin{array}{l}\text { Landscaping the agreed end-state and } \\
\text { go-live }\end{array}$ \\
\hline Project 4 & $\begin{array}{l}\text { Q3/2014 } \\
\text { Q1/2015 }\end{array}$ & $\begin{array}{l}\text { Final and conclusive removal of } \\
\text { components having become } \\
\text { obsolete }\end{array}$ & $\begin{array}{l}\text { Code removal, hardw are } \\
\text { decommissioning, Solution Support } \\
\text { contract termination, hosting } \\
\text { contract termination and license } \\
\text { cancellation }\end{array}$ & $\begin{array}{l}\text { Final and conclusive removal of all } \\
\text { strategic, financial, operational and } \\
\text { technical legacy AFTER operational } \\
\text { acceptance of all landscaping }\end{array}$ \\
\hline
\end{tabular}

The biggest insight from this clean sweep was that local capabilities (i.e. workarounds) in use could be grouped regarding demonstrated best practices, redundant or obsolete. When modelling the to-be system performing the work Enterprise Architects add severe value by addressing all three variants. Demonstrated best practices are opportunities to innovate, while redundant and obsolete capabilities are limiting factors tying resources (both brain power and budget) which should be used to add value to customers. Retaining redundant and obsolete business capabilities is a costly burden and thus competitive disadvantage.

Example 3: "Hypothesis testing at the global level". This case was used to test the clean sweep approach at a truly global level in over 220 countries and territories. This case was the archetype of what happens if Enterprise Architecture focuses on the new only. "WorldNet" was superseded in 2005 and was still fully operational. Six of the capabilities found were hardly used, not updated since 2005 and the associated capabilities were not part of any DHL Express roadmap. The entire infrastructure had several security risks (e.g. code injection into the DHL network) which had to be

${ }^{4}$ The in extensor publication of this longitudinal case study can be found under Köhler et al. (2013). 
removed as part of the sunset. Hence, Enterprise Modeling is also about designing, aligning and agreeing a security risk minimization strategy is addressing the security risks found on the work systems infrastructure. This scope enhancement was managed as part of a Change Request at the project level.

Table 3: Case 3 summary

\begin{tabular}{|c|c|c|c|c|}
\hline Leg & Timeline & Key Task & Scope & Main Output \\
\hline Project 1 & Q1/2014 & $\begin{array}{l}\text { Review of the } 3 \text { legacy components in use } \\
\text { globally in over } 220 \text { countries and territories }\end{array}$ & 10 capabilities found & $\begin{array}{l}\text { Baseline of the capabilities in use and } \\
\text { assessment of their legacy status (including } \\
\text { the assessment of opportunities and limiting } \\
\text { factors based on their status) }\end{array}$ \\
\hline Project 2 & $\begin{array}{l}\mathrm{Q} 2 \text { and } \\
\mathrm{Q} / 2013\end{array}$ & $\begin{array}{l}\text { Design, align and agree on a legacy strategy } \\
\text { for each capability and component found }\end{array}$ & $\begin{array}{l}3 \text { capabilities (all of them globally used } \\
\text { w orkarounds) w ere retained in a secure } \\
\text { environment } \\
7 \text { capabilities classified as obsolete, outdated } \\
\text { or rejected as no longer adding value }\end{array}$ & $\begin{array}{l}\text { Agreed joint course of action and decicive } \\
\text { points to get the system performing the work } \\
\text { in the pre-defined desired end-state }\end{array}$ \\
\hline Project 3 & Q4/2014 & Evolution of the system performing the $w$ ork & $\begin{array}{l}1 \text { stand-alone implementation project for the } 3 \\
\text { capabilities agreed to be retained }\end{array}$ & $\begin{array}{l}\text { Landscaping the agreed end-state and go- } \\
\text { live }\end{array}$ \\
\hline Project 4 & Q1/2015 & $\begin{array}{l}\text { Final and conclusive removal of components } \\
\text { having become obsolete }\end{array}$ & $\begin{array}{l}\text { Code removal, hardw are decommissioning, } \\
\text { Solution Support contract termination, hosting } \\
\text { contract termination and license cancellation }\end{array}$ & $\begin{array}{l}\text { Final and conclusive removal of all strategic, } \\
\text { financial, operational and technical legacy } \\
\text { AFTER operational acceptance of all } \\
\text { landscaping }\end{array}$ \\
\hline
\end{tabular}

Example 4: "Hypothesis testing at country level". In this example, we addressed a legacy landscape after delineating a country cluster (Benelux) setup at work system level into three country-specific work systems for Belgium, Netherlands and Luxemburg.

Table 4: Case 4 summary

\begin{tabular}{|c|c|c|c|c|}
\hline Leg & Timeline & Key Task & Scope & Main Output \\
\hline Project 1 & $\begin{array}{l}\text { Q4/2015 } \\
\text { and } \\
\text { Q1/2016 }\end{array}$ & $\begin{array}{l}\text { Review of the } 16 \text { legacy components in use } \\
\text { in Belgium and Netherlands }\end{array}$ & 734 capabilities found & $\begin{array}{l}\text { Baseline of the capabilities in use and } \\
\text { assessment of their legacy status (including } \\
\text { the assessment of opportunities and limiting } \\
\text { factors based on their status) }\end{array}$ \\
\hline Project 2 & Q2/2016 & $\begin{array}{l}\text { Design, align and agree on a legacy strategy } \\
\text { for each capability and component found }\end{array}$ & $\begin{array}{l}99 \text { capabilities were retained globally (of } \\
\text { which } 6 \text { w ere "Specialist" components) } \\
606 \text { capabilities w ere classified as obsolete, } \\
\text { oudated or w ere rejected as no longer adding } \\
\text { value } \\
29 \text { capabilities w ere redundant }\end{array}$ & $\begin{array}{l}\text { Agreed joint course of action and decicive } \\
\text { points to get the system performing the w ork } \\
\text { in the pre-defined desired end-state }\end{array}$ \\
\hline Project 3 & Q3/2016 & Evolution of the system performing the work & $\begin{array}{l}1 \text { stand-alone implementation project for the } \\
99 \text { capabilities agreed to be retained }\end{array}$ & $\begin{array}{l}\text { Landscaping the agreed end-state and go- } \\
\text { live }\end{array}$ \\
\hline Project 4 & Q3/2016 & $\begin{array}{l}\text { Final and conclusive removal of components } \\
\text { having become obsolete }\end{array}$ & $\begin{array}{l}\text { Code removal, hardw are decommissioning, } \\
\text { Solution Support contract termination, hosting } \\
\text { contract termination and license cancellation }\end{array}$ & $\begin{array}{l}\text { Final and conclusive removal of all strategic, } \\
\text { financial, operational and technical legacy } \\
\text { AFTER operational acceptance of all } \\
\text { landscaping }\end{array}$ \\
\hline
\end{tabular}

Country delineation defined of the 734 capabilities discovered 497 outdated or obsolete. Further capabilities were rejected by Senior Users of which 109 capabilities were deemed not adding value and 29 capabilities were redundant and available in other systems. Those 29 capabilities implied user is readying (i.e. training on the job with the new systems) without any work system components changed.

As this project was about delineation, it was not about innovation in Controlling (42 capabilities), Sales (41 capabilities), Finance (15 capabilities) and Key Account management (1 capability) rather than updating the product, service and solution portfolio itself. Sales, Finance and Key Account management, have an impact on how and organization interacts with customers and how it is perceived by the outside world. 
Hence, modelling customer interaction is classified as being part of the product, service and solution portfolio.

Five of the capabilities to be retained had to be retained outside the global standard application portfolio. Those five were retained as "specialist" components or under an Architecture Concession Agreement.

\section{Conclusions and Implications for Practice}

\subsection{Conclusion 1: Maximizing the value of enterprise architecture calls for bringing it to the work system level}

Enterprise Architecture adds the most value when applied not only at the entire enterprise level but also at the work system level. All four cases at DHL Express share the common work system theory feature that prior Enterprise Modeling an organization it is recommended to the first trawl for current, and future customer needs and then plan their product, service and solution portfolio accordingly. That updated solution portfolio, as well as the legacy status of work systems components in use, are the impetus for Enterprise Architects to design, align, agree and ultimately guide the joint course of action to implement the agreed strategy. In that context, Enterprise Modeling is about how to innovate best the system performing the work to serve a customer.

Enterprise Modeling draws on input from the environment, business strategy, the legacy status of infrastructure, current and future customer needs as well as the aspired product, service and solution portfolio. This stance views Enterprise Architecture as a process to facilitate the execution of a business strategy that includes understanding future and current states of different aspects of the organization in different layers of detail and abstraction. Understanding the work system level becomes key to this organizational understanding.

\subsection{Conclusion 2: Emphasis on customer needs and wishes is essential for maximizing the value of Enterprise Architecture}

The evidence in the four cases supports the view that Enterprise Architecture is preferred to be managed as part of a customer-centric culture and at work system level. All key decision makers (senior users, senior suppliers, and enterprise architects) need to collaborate fully in a joint iterative endeavour of evaluating existing capabilities and deciding how to move to better work system capabilities and greater value for customers.

\subsection{Conclusion 3: The final and conclusive removal of work system components have become obsolete is also in scope every time}

We conclude that Enterprise Modeling needs to address the final and conclusive removal of components having become 
- $\quad$ strategic legacy work system components which support business processes which have been deliberately abandoned and

- financial legacy works system components as they are more expensive to maintain than their profit contribution and

- operational legacy work system components which require a planned evolution to address changes in the work system's environment or infrastructure and

- technical legacy work system components having become End of Life or End of Service are no longer supported.

The final and conclusive removal of components is managed in line with current, and future customer needs as well as their internal added value. This internal added value explicitly includes axing capabilities which do not deliver or are forecasted not to deliver a justifiable cash margin.

\subsection{Conclusion 4: Enterprise Architecture is a key source of competitive advantage}

Enterprise Architecture is a key source of competitive advantage for it facilitates business strategy execution and work system innovation by providing the multilayered organizational understanding, the process for strategy execution and the ongoing evaluation and alignment of projects to the ongoing evolution of the business strategy. Updating Probert et al. (1999) and Koehler et al. (2013) we propose that the alignment of work system in use and current and future customer needs are achieved as depicted below.

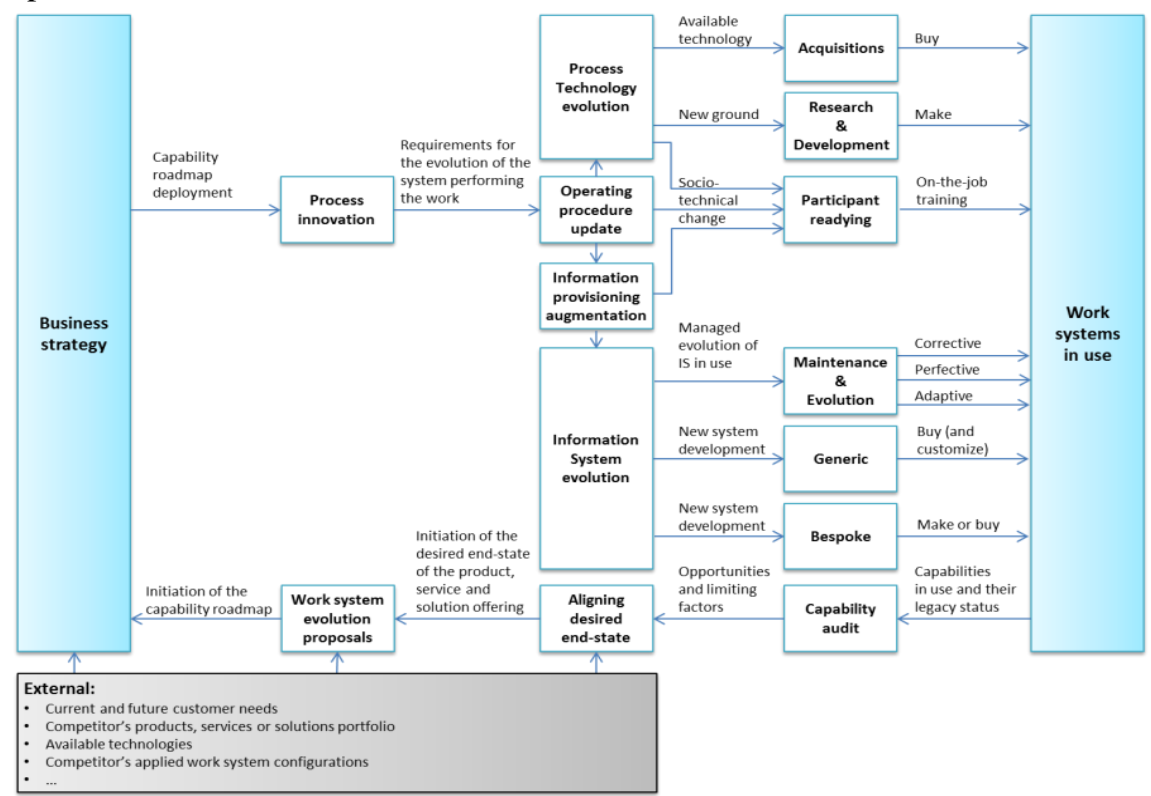

Figure 3: The Köhler, Alter and Cameron Enterprise Architecture cycle 
Key activities in this end-to-end process are to

1) analyze, select and successfully implement work system level innovations to gain and sustain a competitive advantage and

2) plan the further development of existing technological capabilities to create a new and improved product, service or solution offerings and

3) model new or upgrade work systems in use in a way to ensure them being as adaptable as possible to future changes in the business environment and

4) remove all of work system components which have become obsolete.

\subsection{Conclusion 5: A four-leg approach of four stand-alone projects is the preferred way to address current, and future customer needs}

The four legs are stage gates which start with the baseline of a status quo. The baseline of the status quo is the most important information source when modelling a tobe work system, as it surfaces all opportunities and limiting factors to be considered when addressing current and future customer needs within the life cycles of all thirdparty products, services, and partnerships associated with a working system. Based on the findings which are always unique, the second leg is about Enterprise Modeling. Enterprise Modeling is viewed as designing, aligning and agreeing to the desired endstate of a system performing the work. This System performing the work delivers a product, service and solution offering which serves customer needs. The desired-end state includes the final product, service and solution portfolio and the agreed configuration of the system performing the work as well as the portfolio of projects needed to get to that end-state. The third leg is about implementing the agreed course of action. In this third leg, Enterprise Architects are recommended to assure continuous monitoring and adjustments of the project portfolio as changes in business strategy arise. Enterprise architects need to stay with major projects to make sure that the systems produced fit with the enterprise model developed by the key decision makers. The final leg is the clean-up by removing all strategic, operational, financial and technical legacies.

\subsection{Conclusion 6: Enterprise Architecture assurance is a key follow-up activity of Enterprise Modeling}

Enterprise architects need to stay with major projects to make sure that the systems produced fit with the enterprise model developed by the key decision makers. This new Enterprise Architecture Assurance role was perceived as valuable addition to all four leg three and for projects reviewed. Enterprise Architecture Assurance is proposed to be a new standard role in implementation projects. This role is about ensuring that the model delivers the aspired customer promise and also trigger the removal of obsolete legacy systems. 


\section{References}

1. Alter, S. (1995). "How should business professionals analyze information systems for themselves?" pp. 284-299 in E. Falkenberg, et al, Information System Concepts: Toward a Consolidation of Views, Proceedings of the IFIP WG 8.1 Working Conference on Basic Information System Concepts, Marburg, Germany, 1995.

2. Alter, S. (2006) The Work System Method: Connecting People, Processes, and IT for Business Results, Larkspur, CA: Work System Press.

3. Alter, S. (2013). "Work System Theory: Overview of Core Concepts, Extensions, and Challenges for the Future," Journal of the Association for Information Systems, 14 (2), 72 121

4. Bolloju, N., Alter, S., Gupta, A., Gupta, S. and Jain, S. (2017). "Improving Scrum User Stories and Product Backlog Using Work System Snapshots." In Proceedings of the Americas Conference on Information Systems.

5. Bock, A., Kaczmarek, M., Overbeek, S. and Heß, M., (2014) " A Comparative Analysis of Selected Enterprise Modelling Approaches," 7th IFIP Working Conference on The Practice of Enterprise Modelling (PoEM), Springer, Lecture Notes in Business Information Processing, LNBIP-197, pp.148-163, 2014, The Practice of Enterprise Modelling.

6. Bork, D. and Fill, H.G., (2014). "Formal aspects of enterprise modeling methods: a comparison framework." In System Sciences (HICSS), 2014 47th Hawaii International Conference on (pp. 3400-3409). IEEE.

7. Davenport, T. H. (1993) Process Innovation, Harvard Business School Press, Boston.

8. Johne, A. and Storey, C. (1997) New Service Development: A Review Of the Literature and Annotated Bibliography, Management Working Paper: B97/2.

9. Hedeman, B. and Seegers, R. (2010) "Learn PRINCE2 - PRINCE2 2009 Edition - Das Taschenbuch", Van Haren Publishing, Zaltbommel.

10. Karagiannis, D. and Kühn, H., (2002) "Metamodelling platforms." In EC-Web (Vol. 2455, p. 182).

11. Köhler, T. and Alter, S. (2017) "Using Enterprise Architecture to Attain Full Benefits from Corporate Big Data while Refurbishing Legacy Work Systems". Proceedings of the 18th IEEE Conference on Business Informatics, Paris, France.

12. Köhler, T., Cameron, B. H., Sweeney, M. and Harrison, A. S. (2013) "Strategic markettechnology linking in Logistics Work Systems - Evidence from two longitudinal Enterprise Architecture case studies at Deutsche Post DHL". Proceedings of the British Academy Of Management Conference, Liverpool, UK.

13. Rolland, C., Souveyet, C., and Moreno, M. (1995). "An approach for defining ways-ofworking." Information Systems, 20(4), 337-359.

14. Sandkuhl, K., Fill, H.G., Hoppenbrouwers, S., Krogstie, J., Leue, A., Matthes, F., Opdahl, A.L., Schwabe, G., Uludag, Ö. and Winter, R. (2018). "From Expert Discipline to Common Practice: A Vision and Research Agenda for Extending the Reach of Enterprise Modeling." Business \& Information Systems Engineering, 60(1), 69-80.

15. Truex, D., Alter, S. and Long, C. (2010). "Systems analysis for everyone else: Empowering business professionals through a systems analysis method that fits their needs." European Conference on Information Systems.

16. Vernadat, F. B. (1996). Enterprise Modelling and Integration. Chapman \& Hall. 